\title{
RESEARCH
}

Open Access

\section{Magnitude of anemia and associated factors among children aged 6-59 months at Debre Markos referral hospital, Northwest Ethiopia: a hospital-based cross- sectional study}

Yoseph Merkeb Alamneh ${ }^{1 *}$, Tadesse Yirga Akalu², Abtie Abebaw Shiferaw ${ }^{3}$ and Aytenew Atnaf ${ }^{3}$

\begin{abstract}
Background: Anemia, the most common micro-nutrient deficiency disorder, is the world's second leading cause of morbidity and morbidity, affecting $24.8 \%$ of the population, of which $47.4 \%$ are under-five children. The prevalence of anemia ranges from 44 to $56 \%$ in Ethiopia. Although its magnitude has shown decreases across regions; it continues to be a significant public health problem, particularly in developing countries including Ethiopia. Despite this evidence, the magnitude and associated factors of anemia was not systematically explored and there is a limited information or limited evidences in the study area. Hence, the aim of this study was to assess the magnitude and associated factors of anemia among children aged 6-59 months attending at Debre Markos Referral Hospital, Northwest Ethiopia.

Methods: A hospital-based cross-sectional study was conducted at Debre Markos referral hospital Northwest Ethiopia from September 30 to December 30, 2019. Data on socio-demographic and socio-economic factors, health and nutritional features of children and their mothers were obtained using pre-tested structured questionnaires in a face-to-face interview with child care providers. Blood samples and stool examination for intestinal parasites were performed. Hemoglobin level was analyzed using the HemoCue device (HemoCueHb 301). The collected data were coded, cleared and entered into Epi-Data version 3.1, and analyzed using Stata version 14 software. To identify candidates and predictor variables, bivariate and multivariate logistic regressions were applied respectively. The significance level was determined at a confidence interval of $95 \%$ at $p$-value $<0.05$.

Results: Of the total of 341 participants planned to be participated, about 310 mother-child pairs participated in the study, giving a response rate of 91\%; and data were collected from children as well as their parents or guardians.

In this study, the magnitude of anemia was $11.9 \%(95 \% \mathrm{Cl}, 8.5,16.2 \%)$. Poor dietary diversity (AOR=2.3; $95 \% \mathrm{Cl}$ : $1.12,5.14)$, food-insecure households $(A O R=3.24 ; 95 \% \mathrm{Cl}: 1.85,4.52)$, complementary feeding initiation time $(\mathrm{AOR}=$ 3.20; $95 \% \mathrm{Cl}: 1.23,6.61)$, intestinal parasites infection $(\mathrm{AOR}=3.20 ; 95 \% \mathrm{Cl}: 1.23,6.61)$ and family income $(\mathrm{AOR}=2.87$;
\end{abstract}

\footnotetext{
* Correspondence: ymerkeb11@gmail.com

${ }^{1}$ Department of Biomedical Sciences, Debre Markos University, P.O. Box 269, Debre Markos, Ethiopia

Full list of author information is available at the end of the article
}

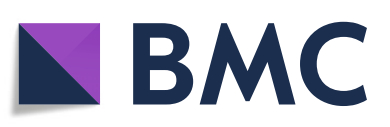

(c) The Author(s). 2021 Open Access This article is licensed under a Creative Commons Attribution 4.0 International License, which permits use, sharing, adaptation, distribution and reproduction in any medium or format, as long as you give appropriate credit to the original author(s) and the source, provide a link to the Creative Commons licence, and indicate if changes were made. The images or other third party material in this article are included in the article's Creative Commons licence, unless indicated otherwise in a credit line to the material. If material is not included in the article's Creative Commons licence and your intended use is not permitted by statutory regulation or exceeds the permitted use, you will need to obtain permission directly from the copyright holder. To view a copy of this licence, visit http://creativecommons.org/licenses/by/4.0/ The Creative Commons Public Domain Dedication waiver (http://creativecommons.org/publicdomain/zero/1.0/) applies to the data made available in this article, unless otherwise stated in a credit line to the data. 
$95 \%$ Cl:1.57, 5.0) were found to be factors significantly associated with anemia.

Conclusion: Overall, anemia is considered a public health problem among children aged 6-59 months attending at Debre Markos referral hospital, based on the cut-off point of the World Health Organization. Poor dietary diversity, complementary feeding initiation time, household food insecurity, intestinal parasite infection and family income were significantly associated with childhood anemia. Thus, it needs for proven interventions in public health such as food diversification, anti-helmintic drug provision and household food security. In addition, educating women about nutrition and diet diversification, as well as involving them in alternative sources of income-generating activity, can be vital in the study area.

Keywords: Anemia, Associated factors, Debre Markos, Northwest Ethiopia

\section{Introduction}

Anemia can be defined as a reduction in the hemoglobin, hematocrit, or red cells number or their capacity to carry oxygen becomes insufficient to meet the physiological needs [1]. Anemia, the most common micro-nutrient deficiency disorder, can affect a person at all stages of life at any time, particularly among children aged 6-59 months and pregnant women, because of their higher iron requirements [2]. According to the World Health Organization (WHO) criteria, anemia is considered in terms of age and sex based on the average hemoglobin levels: Children from 6 months to 6 years old $=11 \mathrm{~g} / \mathrm{dl}$, Children aged 7 to 14 years $=12 \mathrm{~g} / \mathrm{dl}$, Adult men $>15$ years of age $=13 \mathrm{~g} / \mathrm{dl}$, pregnant women $=11 \mathrm{~g} / \mathrm{dl}$, and non-pregnant women $=12 \mathrm{~g} / \mathrm{dl}$ $[3,4]$. In the population, anemia with a magnitude of $40 \%, 20-39.9 \%, 5-19.9 \%$ and $<5 \%$ is graded as severe, moderate, mild and no public health problem, respectively [5]. It is the world's second leading cause of death and morbidity for the entire global burden of disease, affecting 1.62 billion people, accounting for $24.8 \%$ of the population, of whom $47.4 \%$ are children under 5 years of age $[6,7]$. Anemia in children aged $6-59$ months is a major health issue in nearly all developing world countries with an estimated magnitude of about 43\%; with regional disparities of $62.3 \%$ in Africa, 53.8\% in South East Asia and $21.9 \%$ in the Western Pacific region [4]. The magnitude of anemia in children ranges from $5 \%$ in North America to 22\% in Europe and 30-63\% in Asia, $12-58 \%$ in Africa $[8,9]$. The magnitude of anemia among hospitalized children in various parts of Africa has been studied; $56.3 \%$ in Uganda; $83.2 \%$ in Southern Tanzania and $44-56 \%$ in Ethiopia [10-12]. In Ethiopia, anemia affects as many as six out of ten children under 5 years of age, but the proportion varies across the country due to food, income and culture disparities, for example, in the Somali region $83 \%$, in Afar $75 \%$, in Dire Dawa 72\%, in the Amhara region 42\% [13].

Anemia etiology is frequently multifactorial and interrelated in a complex manner, and anemia is correlated with socioeconomic, biological, environmental and nutritional factors such as stunting, low dietary diversity, food scarcity, timely initiation of supplementary feeding, deworming, wasting, educational status, parasite infestations, maternal weight and antenatal care visits [11, 14-18]. There are also numerous root causes of anemia, including blood loss, decreased RBC production, infectious diseases, maternal anemia during pregnancy, although $50 \%$ of its causes are iron deficiencies [19-22]. If left untreated, childhood anemia has severe consequences, including growth retardation, impaired motor and cognitive development, poor school performance, exposure to comorbid diseases, adult anemia predictors and increased morbidity and mortality [23, 24]. It also has adverse effects on economic development, physical, mental and social health [25].

Even its magnitude has shown decreases across regions; it continues to be a significant public health issue worldwide [26]. Although few local studies have shown magnitude of anemia, data on children are not available particularly in our study area. To minimize the anemia impacts, this section of the population needs to be stressed in order to provide an integrated package of interventions. Thus, evidence-based development of possible strategies and response to the problem will contribute significantly. In addition, it is a paramount importance to generate epidemiological data, identify risk factors and determine the magnitude of the anemia that regional and national public policies are being reformed; it is also important for program planners and policy makers to develop adaptable intervention and control strategies for the local context. Furthermore, these factors are more prevalent and with greater focus on the prevention aspects of anemia, concrete evidence is created in which evidence can encourage policymakers and program managers to implement effective intervention to monitor and mitigate the negative consequences of childhood anemia. However, as far as the authors are aware, there was no previous studies in the study area. This study was therefore aimed to explore the 
magnitude of anemia and identify associated factors among children aged 6-59 months at Debre Markos referral hospital, Northwest Ethiopia.

\section{Materials and methods}

Study design, period and area

A hospital-based cross-sectional study was conducted at Debre Markos referral hospital which is located at Debre Markos town, $299 \mathrm{~km}$ northwest of Addis Ababa, the capital city of Ethiopia. The study period was from September 30 to December 30, 2019. The town is situated at a latitude and longitude of $10^{\circ} 21^{\prime} \mathrm{N}$ and $37^{\circ} 42^{\prime} \mathrm{E}$, respectively, with an elevation of $2446 \mathrm{~m}$ above sea level [27]. According to the 2007 population and housing census of Ethiopia, the projected total population of the town was 132,363 , of which $66,314(50.5 \%)$ are female and $66,049(49.5 \%)$ are male [28].

\section{Study population}

All under-five children attending at Debre Markos referral hospital. This study included all children between 6 months and 59 months of age attending at Debre Markos Referral Hospital during the study period. However, children suffered from severe medical or surgical conditions, severe bleeding, iron and vitamin A supplementation over the past 3 months and blood transfused for less than 3 months were excluded from the study.

\section{Sample size determination and sampling technique}

The sample size was determined using a single population ratio formula, and calculated using Open Epi-Data Version 3.1. The following statistical assumptions were considered for calculating our sample size: $p=$ magnitude of anemia $28 \%$ taken from a study conducted in Ethiopia [29], $\mathrm{Z} \alpha / 2$ = the corresponding $\mathrm{Z}$ score of $95 \%$ $\mathrm{CI}$ and $\mathrm{d}=$ Margin of error (5\%).

$$
\begin{gathered}
\frac{\mathrm{n}=(\mathrm{z} \alpha / 2)^{2} \times \mathrm{p}(1-\mathrm{p})}{\mathrm{d}^{2}} \\
\frac{\mathrm{n}=(1.96)^{2} \times 0.28(1-0.28)=310}{(0.05)^{2}}
\end{gathered}
$$

Finally, the final sample size of our analysis was estimated as 341 after adding 10\% of none response rate. It was intended to include all 341 children aged 6-59 months who visited at Debre Markos Referral Hospital consecutively during the study period.

\section{Data collection tools and procedures}

Data were collected via questionnaire administered by interviewees, prepared in English and translated into Amharic language. A pretested structured questionnaire was used through a face-to - face interview to gather socio-demographic and economic data from mothers.
The tools for data collection were developed through review of guidelines and related literatures $[18,30]$. The design of the questionnaire included the following four sections. The first section dealt with the sociodemographic characteristics. The second part dealt with household food service status, assessed using the standardized questionnaire developed by Food and Nutritional Technical Assistance [31]. Part three was designed to identify child feeding practices, the modified version of the Helen Keller International Food Frequency Questionnaire and the 24-h dietary recall were used to identify dietary patterns and dietary diversity scores, respectively, and the fourth part assessed children's morbidity [32, 33].

\section{Measurement of variables \\ Hemoglobin determination and anemia diagnosis}

Concentration of hemoglobin was used to determine the anemia status by taking capillary blood samples. Hemoglobin level was analyzed using the HemoCue device (HemoCueHb 301) and altitude values have been adjusted using WHO guidelines. Anemia has been characterized as having a hemoglobin level below $11 \mathrm{~g} / \mathrm{dl}$. It has been further graded into mild, moderate, and severe anemia. Mild anemia was 10$11 \mathrm{~g} / \mathrm{dl}$ for children with hemoglobin levels while mild anemia was 7-10 g / dl for children with $\mathrm{Hb}$ levels and severe anemia was below $7 \mathrm{~g} / \mathrm{dl}$ for children with hemoglobin levels. The hemoglobin concentration below $11.0 \mathrm{~g} / \mathrm{dl}$ was considered anemic whereas the hemoglobin concentration $11.0 \mathrm{~g} / \mathrm{dl}$ or higher was considered normal. Anemia severity was classified according to the WHO guideline as follows: children were categorized as mild, moderate and severe anemic if their blood hemoglobin concentrations are between $10.0-10.9 \mathrm{~g} / \mathrm{dl}, 7.0-9.9 \mathrm{~g} / \mathrm{dl}$ and $<7.0 \mathrm{~g}$ / dl, respectively [18].

\section{Laboratory analysis}

For the analysis of hematological parameters, about $2 \mathrm{ml}$ of venous blood was collected from each subject; hemoglobin $(\mathrm{Hgb})$ was determined using the HemoCue device (HemoCueHb 301). To examine hemiparasites, thick and thin films of blood were prepared and stained with Giemsa stain. Stool sample was collected and examined for intestinal parasite infection using both direct wet mounting techniques and formol ether concentration.

\section{Outcome variable}

Hemoglobin level below $11 \mathrm{mg} \mathrm{/} \mathrm{dl}$ was taken as dependent variables. 


\section{Independent variables}

Socio-demographic and socioeconomic characteristics: sex of child, age of child (months), age of mother (years), residence, occupation of the mother, number of underfive children, maternal educational status, annually family income; health and nutritional characteristics of children aged 6-59 months and their mothers: initiation of complementary feeding, complementary feeding frequency/day, intestinal parasites,, dietary diversity score, vaccination status, antenatal care follow-up, place of delivery, maternal anemia, household food insecurity, mothers' meal frequency / day were independent variables.

\section{Data quality assurance and control}

The questionnaire was prepared in English, translated into the local (Amharic) language and then translated back into English to check consistency. After training was given on the study objective, consenting, data collection techniques, data were collected by trained data collectors. Investigators closely monitored the data collection process. All measurements were taken by following the recommendation of the manufacturers. All percentage of technical error measurement (\%TEM) values for either inter- or intra-observer reliability of anthropometric data measurement was classified as 'acceptable' $(<2 \%)$, and coefficients of reliability greater than $99 \%$.

\section{Data management, analysis and interpretation}

Data were entered into the Epi-Data version 3.1 software and analyzed with Stata version 14 software. Data cleaning was carried out to check the frequency, accuracy, consistency and missed values; any identified errors were corrected. Proportions, means and standard deviations (SD) were used to describe independent variables and anemia in the study population. In order to identify candidate variables $(p$-value $<0.25)$ for multivariate regression, bivariate logistic regression was done using independent variables. In the bivariate analysis, variables with a $p$-value of $<0.25$ were fitted into the multivariate analysis of binary logistic regression. Finally, predictors of anaemia were determined among the selected candidate variables using multivariate logistic regression model. Interaction, mediation, and multi co-linearity between independent variables were checked on the basis of assumptions such as tolerance, variance inflation factors (VIF), interaction correlation coefficient and others to ensure the fitness of the logistic regression model. Multicollinearity was assessed by examining Variance Inflation Factor (VIF) and others, which assesses how much the variance of an estimated regression coefficient increases if predictors are correlated, a value of VIF were in acceptable range (less 5), indicates that there is no correlation between this independent variable. The final model was tested for its fitness by Hosmer and Lemeshow $p$-value and $p$-value was 0.73 considered good fitness of the model [34]. To show the strength of the association, both the crude odds ratio (COR) and the adjusted odds ratio (AOR) with the corresponding 95\% confidence interval (CI) were calculated. The statistical significance was determined in the multivariate analysis at a confidence interval of $95 \%$ at $p$-value $<0.05$.

\section{Ethical approval and consent}

The actual gathering of data was started after the study was approved by Debre Markos University. Local administrative bodies were also communicated about the study, and permission was obtained prior to the study. Finally, informed written consent obtained from the mothers / caregivers.

\section{Results}

Socio-demographic and socioeconomic characteristics

In this study, a total of 310 mother-child pairs were participated, giving a response rate of $91 \%$. Majority of the respondents were male $162(52.3 \%)$. The age range of children was 6 to 59 months and the mean ages were $28.7 \pm 4.302$ months. Most of study participants $(64 \%)$ have greater than two children and about $53.3 \%$ had greater than annual income of 10,000 ETB (Table 1).

\section{Health and nutrition characteristics}

Among the study participants, about two hundred and nineteen children (70.6\%) started complementary feeding at the 6th month and above. Moreover, the children had a mean dietary diversity score of 3.4 with a standard deviation of 1.5 , and only 124 (40\%) consumed more than half of the recommended seven food groups. The magnitude of maternal anemia was $30.3 \%$, of which 233 $(75.2 \%)$ consumed less than four meals a day. Seventyeight (25.1\%) mothers fully attended the four ANC visits recommended by the WHO, while only 48 (15.5\%) did not have an ANC visit. Based on the Measurement of Household Food Insecurity Access Scale (HFIAS), 140 (45.2\%) of children were born and live-in food-secure households, while the rest were born and live-in foodinsecure households (Table 2).

\section{Magnitude and severity of anemia}

The overall magnitude of anemia among children aged 6-59 months was, $11.9 \%$ (95\% CI: 8.5-16.2\%) with hemoglobin levels below $11 \mathrm{~g} / \mathrm{dl}$. Among anemic cases, the majority were mild $(10-10.9 \mathrm{~g} / \mathrm{dl})$ and moderate (7-9.9 g / dl) anemics with 22 (7.1\%) and 11 (3.5\%) respectively; while only $4(1.3 \%)$ children were seriously anemic with hemoglobin levels below $7 \mathrm{~g} / \mathrm{dl}$. 
Table 1 Socio demographic characteristics of children age 659 months at Debre Markos Referral Hospital, Northwest Ethiopia, 2019

\begin{tabular}{lll}
\hline Variables $(\boldsymbol{n}=\mathbf{3 1 0})$ & Categories & $\mathbf{n}(\%)$ \\
\hline Sex of child & Male & $162(52.3)$ \\
Age of child (months) & $6-11$ & $148(47.7)$ \\
& $12-23$ & $62(20.0)$ \\
& $24-35$ & $83(26.8)$ \\
& $36-47$ & $67(21.6)$ \\
Age of mother (years) & $48-59$ & $47(15.2)$ \\
Residence & $15-29$ & $51(16.5)$ \\
Occupation of the mother & $30-49$ & $182(58.7)$ \\
& Urban & $128(41.3)$ \\
& Rural & $209(67.4)$ \\
& House wife & $101(33.6)$ \\
Annually family income (ETB) & $108(34.8)$ \\
& Self employed & $33(10.7)$ \\
& Employed & $93(30.0)$ \\
& Farmer & $76(24.5)$ \\
Number of under-five children & One child & $113(36.5)$ \\
& Two \& above children & $197(64.5)$ \\
Maternal educational status & Unable to read \& write & $70(22.6)$ \\
& Primary school & $57(18.4)$ \\
& Secondary school & $73(23.5)$ \\
& College/ University & $110(35.5)$ \\
& $145(46.7)$ \\
& $165(53.3)$ \\
\hline
\end{tabular}

\section{Factors associated with anemia}

Based on bivariate logistic regression, anemia among children aged 6-59 months was associated with age of child, age of mother, annual family income, complementary feeding initiation period, intestinal parasites, dietary diversity score and food insecurity $(p<0.05)$. However, in the multivariable logistic regression analysis, children's age, mothers' age was not associated with childhood anemia $(p>0.05)$; whereas in the multivariable logistic regression analysis, the initiation time of complementary feeding, intestinal parasites, annual family income, dietary diversity score and household food insecurity were identified as predictors of child anemia $(p<0.05)$. Depending on the multivariable logistic regression logistic regression, the nutritional aspects of childhood anemia have also been found to be predictive factors. Children consuming poor dietary diversity $(\mathrm{DDS}<4)$ were therefore found to be more likely to be anemic than their counterparts $(\mathrm{AOR}=2.3 ; 95 \% \mathrm{CI}$ : 1.12, 5.14). In addition, children from food deprived households were three times more likely to be anemic than those from food-secure households $(\mathrm{AOR}=3.24$;
95\% CI: $1.85,4.52)$. The odds of developing anemia among children aged 6-59 months with annual family income of $\leq 10,000$ ETB were nearly three times higher compared with annual family income of $>10,000$ ETB $(\mathrm{AOR}=2.87 ; 95 \% \mathrm{CI}: 1.57,5.0)$. Similarly, starting of the complimentary feeding before 6 months, the chances of anemia were three times higher than those of children who started supplemental feeding after 6 months. In addition, the chances of developing anemia were three times higher among individuals with intestinal parasites $(\mathrm{AOR}=3.20$; 95\% CI:1.23, 6.61). (Table 3).

\section{Discussion}

The purpose of this study was to determine the magnitude and associated factors of anemia in children aged 6-59 months who visited Debre Markos Referral Hospital in Northwest Ethiopia. Despite the progress of nutritional interventions, anemia remains one of the major health problems in developing countries resulting in serious health outcomes, particularly among children aged 6-59 months and pregnant women [2]. It is a moderate to severe public health issue that has been significantly associated with negative effects on the overall health of children, social and economic development $[35,36]$. According to the report by the WHO and the United Nations on progress towards the Millennium Development Goals (MDGs), although significant progress has been made towards achieving MDG4 to reduce the number of under-five mortality rates worldwide, the rate of decline remains insufficient to meet the stated goal in developing countries,including Ethiopia [37, 38]. This raises concerns about the future and effectiveness of interventions that reduce anemia, because the magnitude of anemia is a powerful indicator for assessing the impact and effectiveness of interventions [2].

In this study, the overall magnitude of anemia among children aged 6-59 months was found to be $11.9 \%$ (95\% CI: $8.5-16.2 \%)$. It is a public health problem that should be addressed using appropriate preventive strategies as anemia contributes to childhood morbidity and mortality [39]. According to the WHO, if the magnitude is greater than $5 \%$, anemia is considered a public health problem, however, the magnitude of the problem is defined as mild, moderate and severe when the magnitude is 5$19.9 \%, 20-39,9 \%$ and $\geq 40 \%$ respectively [40]. Consequently, there is a mild public health problem in the study area that should be addressed using appropriate preventive methods as anemia leads to child morbidity and mortality [39]. This finding is comparatively close to other local studies carried out at Mekelle (11\%) [30, 41], but higher than the study done at Addis Ababa (5.83\%) [42]. Also this study was comparatively close to other local studies carried out in Lithuania (10.1\%) [43], Serbia (10.8\%) [44], Mexico (12\%) [45], and Brazil (9.3\%) [41]. 
Table 2 Health and nutritional characteristics of children aged 6-59 months and their mothers at Debre Markos Referral Hospital, Northwest Ethiopia, 2019

\begin{tabular}{|c|c|c|}
\hline Variables $(n=310)$ & Categories & n (\%) \\
\hline \multirow[t]{2}{*}{ Initiation of complementary feeding } & $<6$ months & $91(29.4)$ \\
\hline & $\geq 6$ months & $219(70.6)$ \\
\hline \multirow[t]{2}{*}{ Complementary feeding frequency/day } & $\leq 3$ & $202(65.2)$ \\
\hline & $>3$ & $108(34.8)$ \\
\hline \multirow[t]{2}{*}{ Intestinal parasites } & Yes & $214(69.0)$ \\
\hline & No & $96(31.0)$ \\
\hline \multirow[t]{2}{*}{ Dietary diversity score } & Below 4 & $186(60)$ \\
\hline & 4 and above & $124(40)$ \\
\hline \multirow[t]{2}{*}{ Fully vaccinated } & Yes & $273(88.0)$ \\
\hline & No & $37(12.0)$ \\
\hline \multirow[t]{3}{*}{ Antenatal care follow-up } & No visit & $48(15.5)$ \\
\hline & $1-3$ visit & $184(59.4)$ \\
\hline & 4 and above & $78(25.1)$ \\
\hline \multirow[t]{2}{*}{ Place of delivery } & Home & $130(41.9)$ \\
\hline & Health facility & $180(58.1)$ \\
\hline \multirow[t]{2}{*}{ Maternal anemia } & Yes & $94(30.3)$ \\
\hline & No & $216(69.7)$ \\
\hline \multirow[t]{4}{*}{ Household food insecurity } & Food secure & $140(45.2)$ \\
\hline & Mildly food insecure & $50(16.1)$ \\
\hline & Moderately food insecure & $78(25.2)$ \\
\hline & Severely food insecure & $42(13.5)$ \\
\hline \multirow[t]{2}{*}{ Mothers' meal frequency / day } & $\leq 3$ & $233(75.2)$ \\
\hline & $>3$ & $77(24.8)$ \\
\hline
\end{tabular}

This could be explained by the high magnitude of chronic early childhood undernutrition in study area based on the 2016 DHS reports [46]. Furthermore, the possible explanations for variations in the magnitude of anemia between the present study and the above studies may be related to the seasonal and geographical variation of risk factors and disparities in the socioeconomic status of the populations.

The current study findings were lower than the studies done at Kersa (27.1\%) [47], Filtu (23.66\%) [48], LiboKemkem and Fogera districts (30.9\%) [49], Kenya (28.835.3\%) [50], West Africa (23.8\%) [51], China 34\% [52]. The potential reason for this study's low magnitude of anemia may be attributed to variations in the research timeframe and the impact of the biannual deworming system which is a major public health initiative recently initiated by government to minimize intestinal infection by offering antihelmintics.

In this research, household income has also been associated with anemia among children. Children living in households with lower monthly incomes were more likely to suffer from anemia than those with higher incomes. This is supported by similar findings in a study carried out in Brazil and northern Ethiopia [53, 54]. This is because children from poor families are less likely to get iron-rich foods such as animal products and less likely to be able to afford health care during illness due to poverty. It is, therefore, necessary to engage women in income-generating activities so that their children have better health care and supplementary food.

In addition, children eating low dietary diversity were found to be more likely to be anemic than their counterparts according to this report. Children who were given less than four food categories per day were 1.71 times more likely than their peers to develop anemia, and children who were food insecure were 2.87 times more likely than their counterparts to develop anemia $[55,56]$. This might be attributed to the absence of nutritious meals with high protein quality, enough micronutrient content and bioavailability, macro-minerals, iron, and essential fatty acids in children from food insecure homes, all of which raise the risk of childhood anemia [57]. This might be attributed to the seasonal shortage of citric fruits, which aid iron absorption, as well as social and 
Table 3 Bivariate and Multivariable analysis of factors associated with anemia among children aged 6-59 months at Debre Markos referral hospital, Northwest, Ethiopia, 2019

\begin{tabular}{|c|c|c|c|c|c|c|}
\hline \multirow[t]{2}{*}{ Variables } & \multirow[t]{2}{*}{ Categories } & \multicolumn{2}{|l|}{ Anemia status } & \multirow[t]{2}{*}{ COR $(95 \% \mathrm{Cl})$} & \multirow[t]{2}{*}{ AOR $(95 \% \mathrm{Cl})$} & \multirow{2}{*}{$\begin{array}{l}P \text { value } \\
\text { for } \\
\text { AOR }\end{array}$} \\
\hline & & Anemic $\mathrm{n}(\%)$ & Non anemic $\mathrm{n}(\%)$ & & & \\
\hline \multirow[t]{2}{*}{ Sex of child } & Female & $20(13.5 \%)$ & $128(86.5 \%)$ & $1.33(0.67-2.65)$ & - & - \\
\hline & Male & $17(13.5 \%)$ & 145(86.5\%) & 1 & & \\
\hline \multirow[t]{5}{*}{ Childs' age in months } & $6-11$ & $15(40.5 \%)$ & $47(59.5 \%)$ & $4.68(1.27-17.3) *$ & $3.62(0.83-6.5)$ & 0.849 \\
\hline & $12-23$ & $9(24.5 \%)$ & $74(76.5 \%)$ & $1.78(0.46-6.94)$ & $2.34(0.40-13.6)$ & 0.343 \\
\hline & $24-35$ & $5(13.5 \%)$ & 62(86.5\%) & $1.18(0.27-5.21)$ & $0.83(0.12-5.56)$ & 0.778 \\
\hline & $36-47$ & $3(8.1 \%)$ & $44(91.9 \%)$ & $1.59(0.36-7.07)$ & $0.76(0.12-4.88)$ & 0.171 \\
\hline & $48-59$ & $5(13.5 \%)$ & $62(86.5 \%)$ & 1 & 1 & \\
\hline \multirow[t]{2}{*}{ Mothers' age in years } & $15-29$ & $21(11.5 \%)$ & $161(89.5 \%)$ & 1 & 1 & \\
\hline & $30-49$ & $16(12 \%)$ & 128(89.1\%) & $4.13(2.6-18.3) *$ & $2.54(0.35-5.34)$ & 0.471 \\
\hline \multirow[t]{2}{*}{ Residence } & Urban & $17(8.1 \%)$ & 192(91.9\%) & 1 & 1 & \\
\hline & Rural & $20(19.8 \%)$ & $81(80.2 \%)$ & $2.79(1.39-5.60)$ & $2.52(0.67-9.47)$ & 0.114 \\
\hline \multirow[t]{3}{*}{ Mothers' occupation } & employed & $9(7.1 \%)$ & $117(92.9 \%)$ & 1 & 1 & \\
\hline & House wife & $10(9.3 \%)$ & $98(90.7 \%)$ & $0.25(0.11-0.59)$ & $4.50(0.69-29.1)$ & 0.818 \\
\hline & Farmer & 18(23.7\%) & $58(76.3 \%)$ & $0.33(0.14-0.760)$ & $1.17(0.30-4.61)$ & 0.707 \\
\hline \multirow[t]{3}{*}{ mothers' educational Level } & Unable to read & $22(31.4 \%)$ & $48(68.6 \%)$ & $0.162(0.7-0.38)$ & $0.10(0.03-0.38)$ & 0.234 \\
\hline & $\begin{array}{l}\text { Primary and secondary } \\
\text { school }\end{array}$ & $9(6.9 \%)$ & 121(93.1\%) & $0.13(0.05-0.33)$ & $0.07(0.01-0.47)$ & 0.206 \\
\hline & College \& above & $6(5.5 \%)$ & $104(94.5 \%)$ & 1 & 1 & \\
\hline \multirow[t]{2}{*}{ Annual family income } & $\leq 10,000$ ETB & $30(20.7 \%)$ & 115(79.3\%) & $5.89(2.50-13.87) *$ & $2.87(1.57-5.0) * *$ & 0.004 \\
\hline & $>10,000$ ETB & $7(4.2 \%)$ & 158(95.8\%) & 1 & 1 & \\
\hline \multirow[t]{2}{*}{ Complimentary food starting } & $<6$ months & $20(21.9 \%)$ & $71(79.1 \%)$ & $3.35(1.66-6.75) *$ & $3.38(1.32-8.64) * *$ & 0.016 \\
\hline & $\geq 6$ months & $17(7.8 \%)$ & 202(92.2\%) & 1 & 1 & \\
\hline \multirow[t]{2}{*}{ Intestinal parasites } & Yes & 198(92.5\%) & $16(7.5 \%)$ & $3.45(0.72-6.99) *$ & $3.20(1.23-6.61) * *$ & 0.024 \\
\hline & No & $21(21.8 \%)$ & $75(78.2 \%)$ & 1 & 1 & 0.445 \\
\hline \multirow[t]{2}{*}{ Child history of anemia } & Yes & $2(33.3 \%)$ & $4(66.6 \%)$ & 1 & 1 & \\
\hline & No & $35(11.5 \%)$ & $269(88.5 \%)$ & $0.26(0.05-1.47)$ & $2.82(0.20-40.4)$ & 0.317 \\
\hline \multirow[t]{2}{*}{ Place of delivery } & Home & $8(6.2 \%)$ & $122(93.8 \%)$ & $1.71(0.69-4.22)$ & $2.54(0.56-5.81)$ & 0.158 \\
\hline & Health facility & $29(10.1 \%)$ & $151(89.9 \%)$ & 1 & 1 & \\
\hline \multirow[t]{2}{*}{ Hospital stay of child } & 1 day & $32(11.7 \%)$ & $241(88.3 \%)$ & 1.18(0.43_3.24) & - & - \\
\hline & $>1$ day & $5(13.5 \%)$ & $32(86.5 \%)$ & 1 & & \\
\hline \multirow[t]{2}{*}{ Number of Children } & One child & $10(8.8 \%)$ & 103(91.2\%) & 1 & 1 & \\
\hline & 2 \&abo child & $27(13.7 \%)$ & $170(86.4 \%)$ & $0.61(0.28-1.32)$ & $1.416(0.44-4.55)$ & 0.559 \\
\hline \multirow[t]{2}{*}{ Dietary diversity score } & Below 4 & 99 & 87 & $6.6(3.76-11.59) *$ & $2.3(1.12-5.14) * *$ & $\leq 0.001$ \\
\hline & 4 and above & 20 & 104 & 1 & 1 & \\
\hline \multirow[t]{2}{*}{ Household food insecurity } & Yes & 55 & 85 & 1 & 1 & \\
\hline & No & 87 & 163 & $1.21(0.8-1.86)$ & $3.24(1.85-4.52) * *$ & $\leq 0.001$ \\
\hline
\end{tabular}

*significant variables of bivariate analysis

**significant variables of multivariate analysis

economic constraints to obtaining animal-based meals like meat. As a result, it is essential to educate the community about the need of giving iron-rich foods to all children.

Similarly, beginning of the complimentary feeding before 6 months, the chances of anemia were three times higher than those of children who started supplemental feeding after 6 months. This study is consistent with a study conducted in northern Ethiopia, Lebanon, Brazil and China [14, 58-60], early solid or liquid meal introduction is linked to childhood anemia. Infections and 
mal-absorption are more likely in newborns who are exposed before the age of 6 months. This might be due to a lack of awareness about the necessity of exclusive breast feeding for infants; as a result, they introduce cow milk at least 6 months earlier. Consequently, the early initiation of supplementary feeding like cow's milk before the age of 6 months does not substitute iron-rich diets, which may lead to iron deficiency anemia [61].

Once more, the magnitude of anemia was substantially high in children with intestinal parasite infection, which is confirmed by research from Tanzania and Nigeria [62, 63]. This may be because the majority of intestinal parasites, particularly hookworm and hemoparasites like malaria, contribute to blood loss and/or red cell destruction and thus contribute to anemia. Deworming is thus an essential intervention in children because intestinal parasites, particularly hookworm infection, lead to blood loss in the intestines, which in turn contributes to anemia. This study has some limitations: The first limitation of this study is that subclinical infections other than intestinal parasites and malaria have not been evaluated, thus limiting the study's generalizability for possible risk factors. This research is quantitative; if qualitative approach was also used it would be stronger to examine the extra determinants of anemia. This research was often revealing of maternal bias as they recalled their previous past. Also, anthropometry-related measurement errors may have been introduced. Using small samples, it's difficult to generalize to society at large. Therefore, larger studies need to demonstrate true associations in the population. Despite these limitations, it is the first hospital-based crosssectional study that has attempted to show the magnitude and associated factors of childhood anemia severity in the study area, which contributes greatly to improving the health of children aged 6-59 months.

\section{Conclusion}

Overall, anemia is considered a public health problem among children aged 6-59 months attending at Debre Markos referral hospital, based on the cut-off point of the World Health Organization. Poor dietary diversity, complementary feeding initiation time, household food insecurity, intestinal parasite infection and family income were significantly associated with childhood anemia. Thus, this needs for proven interventions in public health such as food diversification, anti-helmintic drug provision and household food security. In addition, educating women about nutrition and diet diversification, as well as involving them in alternative sources of income-generating activity, can be vital in the study area. On top of that, more extensive longitudinal studies using a larger sample size, including analysis of all indices of red blood cells, red cell morphology, serum micronutrient levels and subclinical infections, should be conducted to establish a causal-effect relationship between anemia and its contributing factors.

\section{Abbreviations}

AOR: Adjusted Odds Ratio; ANC: Antenatal care; BAZ: Body Mass Index-forAge Z-scores; Cl: Confidence Interval; COR: Crude Odds Ratio; DDS: Dietary Diversity Score; ETB: Ethiopian Birr HAZHeight-for-Age Z-scores;

Hb: Hemoglobin; HFSS: Household Food Security Status; MDG: Millennium Development Goals; RBC: Red Blood Cell; SD: Standard Deviation;

WHO: World Health Organization.

\section{Acknowledgments \\ The authors extend their gratitude to Debre Markos University for the approval of ethical clearance, hospital administrators, data collectors and respondents involved in this research, and all individuals for their cooperation in this study.}

\section{Authors' contributions}

YMA and AA: Approved the proposal with some revisions, developed the design and methodology of the study, literature review, quality evaluation, statistical analysis, data interpretation and drafting of the manuscript. YMA, AA, AAS and TYA: Wrote the proposal, participated in data collection, and analyzed the data. They were also participated in statistical analysis and interpretation, quality assessment, prepared the final draft of the manuscript. Finally, all authors read and approved the final manuscript.

Funding

No funding was obtained for this study.

\section{Availability of data and materials}

The datasets used and/or analyzed during the current study are available from the corresponding author on reasonable request.

\section{Declarations}

Ethics approval and consent to participate

The ethical clearance letter has been received from the research and review committee at Debre Markos University. Additionally, prior to beginning data collection permission was obtained from the hospital authority. Finally, an informed written consent was received from each participant mothers after explaining to them the research objectives. The participants were briefed on the study's purpose, procedures, potential risks, and benefits. In addition, the participants were told that failure to agree to or withdraw from the study would not change or endanger their access to treatment.

\section{Consent for publication}

Not applicable.

\section{Competing interests}

The authors state no competing interests.

\section{Author details}

${ }^{1}$ Department of Biomedical Sciences, Debre Markos University, P.O. Box 269, Debre Markos, Ethiopia. '2Department of Nursing, College of Health Science, Debre Markos University, Debre Markos Ethiopia, P.O. Box 269, Debre Markos, Ethiopia. ${ }^{3}$ Department of Medical Laboratory Science, Debre Markos University, P.O. Box 269, Debre Markos, Ethiopia.

Received: 17 June 2020 Accepted: 5 August 2021

Published online: 13 August 2021

\section{References}

1. World Health Orgnanization: health topics on Anemia which is available at http://www.who.int/topics/anaemia/en/.

2. Pasricha S-R, Black J, Muthayya S, Shet A, Bhat V, Nagaraj S, et al. Determinants of anemia among young children in rural India. Pediatrics. 2010;126(1):e140-9. https://doi.org/10.1542/peds.2009-3108.

3. Heffron R, Thomson K, Celum C, Haberer J, Ngure K, Mugo N, et al. Fertility intentions, pregnancy, and use of PrEP and ART for safer conception among east African HIV serodiscordant couples. AIDS Behav. 2018;22(6):1758-65. https://doi.org/10.1007/s10461-017-1902-7.

4. Breiman RF, Olack B, Shultz A, Roder S, Kimani K, Feikin DR, et al. Healthcareuse for major infectious disease syndromes in an informal settlement in Nairobi, Kenya. J Health Popul Nutr. 2011;29(2):123. 
5. Geneva S: Haemoglobin Concentrations for the Diagnosis of Anaemia and Assessment of Severity. Vitamin and Mineral Nutrition Information System. Document Reference WHO. In.: NMH/NHD/MNM/11.1. http://www.who.int/ entity/vmnis/indicators/haemoglobin ... . 2011.

6. Harika R, Faber M, Samuel F, Mulugeta A, Kimiywe J, Eilander A. Are low intakes and deficiencies in iron, vitamin a, zinc, and iodine of public health concern in Ethiopian, Kenyan, Nigerian, and south African children and adolescents? Food Nutr Bull. 2017;38(3):405-27. https://doi.org/10.1177/03 79572117715818.

7. Herrador Z, Sordo L, Gadisa E, Buño A, Gómez-Rioja R, Iturzaeta JM, et al Micronutrient deficiencies and related factors in school-aged children in Ethiopia: a cross-sectional study in Libo Kemkem and Fogera districts, Amhara Regional State. PLoS One. 2014;9(12):e112858.

8. Getaneh Z, Enawgaw B, Engidaye G, Seyoum M, Berhane M, Abebe Z, et al. Prevalence of anemia and associated factors among school children in Gondar town public primary schools, northwest Ethiopia: a school-based cross-sectional study. PLoS One. 2017:12(12):e0190151.

9. Abebe Z, Takele WW, Anlay DZ, Ekubagewargies DT, Getaneh Z, Abebe M, et al. Prevalence of anemia and its associated factors among children in Ethiopia: a protocol for systematic review and meta-analysis. EJIFCC. 2018; 29(2):138-45.

10. Mghanga FP, Genge CM, Yeyeye L, Twalib Z, Kibopile W, Rutalemba FJ, et al. Magnitude, severity, and morphological types of anemia in hospitalized children under the age of five in Southern Tanzania. Cureus. 2017;9(7): e1499.

11. Gebreegziabiher G, Etana B, Niggusie D. Determinants of anemia among children aged 6-59 months living in Kilte Awulaelo Woreda, northern Ethiopia. Anemia. 2014;2014:1-9. https://doi.org/10.1155/2 014/245870

12. Agegnehu CD, Tesema GA, Teshale AB, Alem AZ, Yeshaw $Y$, Kebede $S A$, et al. Spatial distribution and associated factors of iron supplementation use among pregnant women in Ethiopia; Ethiopian Demographic and health survey 2016 data: spatial and multilevel logistic regression analysis; 2020.

13. Demographic E. Health survey 2011 central statistical agency Addis Ababa. Maryland: Ethiopia ICF International Calverton; 2012. p. 70-71.

14. Woldie $\mathrm{H}$, Kebede $\mathrm{Y}$, Tariku A. Factors associated with anemia among children aged 6-23 months attending growth monitoring at Tsitsika health center, wag-Himra zone, Northeast Ethiopia. J Nutr Metab. 2015;2015: 928632.

15. Jemal Y, Haidar J, Makau WK. The magnitude and determinants of anaemia among refugee preschool children from the Kebribeyah refugee camp, Somali region, Ethiopia. South Afr J Clin Nutr. 2017;30(1):1-6. https://doi. org/10.1080/16070658.2017.1237446.

16. Tiku YS, Mekonnen TC, Workie SB, Amare E. Does Anaemia have major public health importance in children aged 6-59 months in the Duggina Fanigo District of Wolaita zone, southern Ethiopia? Ann Nutr Metab. 2018; 72(1):3-11. https://doi.org/10.1159/000484324.

17. Malako BG, Teshome MS, Belachew T. Anemia and associated factors among children aged 6-23 months in Damot Sore District, Wolaita zone, South Ethiopia. BMC Hematol. 2018;18(1):14. https://doi.org/10.1186/s12878018-0108-1.

18. Alemayehu M, Meskele M, Alemayehu B, Yakob B. Prevalence and correlates of anemia among children aged 6-23 months in Wolaita Zone, Southern Ethiopia. PLoS One. 2019;14(3):e0206268.

19. Beard JL. Iron requirements in adolescent females. J Nutr. 2000;130(2):440S2S. https://doi.org/10.1093/jn/130.2.440S

20. Halterman JS, Kaczorowski JM, Aligne CA, Auinger P, Szilagyi PG. Iron deficiency and cognitive achievement among school-aged children and adolescents in the United States. Pediatrics. 2001;107(6):1381-6. https://doi. org/10.1542/peds.107.6.1381.

21. van den Broek NR, Letsky EA. Etiology of anemia in pregnancy in South Malawi. Am J Clin Nutr. 2000;72(1):247S-56S. https://doi.org/10.1093/ajcn/ 72.1.2475

22. Groce N, Challenger E, Kerac M, Cheshire L. Stronger together: nutritiondisability links and synergies-briefing note. Nutrition working group, global partnership for children with disabilities. New York: Unicef; 2013.

23. Dary O, Hurrell R. Guidelines on food fortification with micronutrients. Geneva: World Health Organization, Food and Agricultural Organization of the United Nations; 2006.

24. Gessner BD. Early childhood hemoglobin level is a strong predictor of hemoglobin levels during later childhood among low-income Alaska children. Int J Circumpolar Health. 2009;68(5):459-70. https://doi.org/10.34 02/ijch.v68i5.17378.

25. Grantham-McGregor S, Ani C. A review of studies on the effect of iron deficiency on cognitive development in children. J Nutr. 2001;131(2):649S68S. https://doi.org/10.1093/jn/131.2.649S.

26. Brabin BJ, Premji Z, Verhoeff F. An analysis of anemia and child mortality. J Nutr. 2001;131(2):636S-48S. https://doi.org/10.1093/jn/131.2.636S.

27. Lumley J. Defining the problem: the epidemiology of preterm birth. BJOG Int J Obstet Gynaecol. 2003;110:3-7. https://doi.org/10.1016/S14700328(03)00011-9.

28. Commission PC: Summary and statistical report of the 2007 population and housing census. Population size by age and sex 2008.

29. Melku M, Alene KA, Terefe B, Enawgaw B, Biadgo B, Abebe M, et al. Anemia severity among children aged 6-59 months in Gondar town, Ethiopia: a community-based cross-sectional study. Ital J Pediatr. 2018;44(1):107. https:// doi.org/10.1186/s13052-018-0547-0.

30. Ababa A, Calverton E. Central statistical Agency (Ethiopia) and ICF international: Ethiopia and Calverton MD Ethiopia Demographic and Health Survey; 2011.

31. Coates J, Swindale A, Bilinsky P. Household food insecurity access scale (HFIAS) for measurement of food access: indicator guide: version 3; 2007.

32. Amare B, Moges B, Moges F, Fantahun B, Admassu M, Mulu A, et al. Nutritional status and dietary intake of urban residents in Gondar, Northwest Ethiopia. BMC Public Health. 2012;12(1):752. https://doi.org/10.11 86/1471-2458-12-752.

33. Belachew T, Lindstrom D, Gebremariam A, Hogan D, Lachat C, Huybregts L, et al. Food insecurity, food based coping strategies and suboptimal dietary practices of adolescents in Jimma zone Southwest Ethiopia. PLoS One. 2013;8(3):e57643.

34. Febyawan D. Estimasi asosiasi perilaku merokok melalui aspek psikologi manusia= estimating the association of smoking behavior through human psikological aspects: Universitas Pelita Harapan; 2020.

35. Smith RE Jr. The clinical and economic burden of anemia. Am J Manag Care. 2010;16:S59-66.

36. Alcázar L. The economic impact of anaemia in Peru. Lima: Group for the Analysis of Development and Action Against Hunger. Animal Genetics. 2013;39:561-3.

37. Avison WR, Davies L. Family structure, gender, and health in the context of the life course. J Gerontol Series B Psychol Sci Soc Sci. 2005;60(Special_ Issue_2):S113-6.

38. Organization WH. WHO STEPS surveillance manual: the WHO STEPwise approach to chronic disease risk factor surveillance. Geneva: World Health Organization; 2005.

39. Organization $\mathrm{WH}$. WHO multicentre growth reference study group: WHO child growth standards: length/height-for-age, weight-for-age, weight-forlength, weight-for-height and body mass index-for-age: methods and development, vol. 2007. Geneva: WHO; 2006.

40. Unicef $\mathrm{U}, \mathrm{WHO}$ U. WHO: Iron deficiency anaemia: assessment, prevention, and control. A guide for programme managers; 2001.

41. da Silva FH, de Assunção Bezerra MK, de Assunção ML, de Menezes RCE. Prevalence of and factors associated with anemia in school children from Maceió, northeastern Brazil. BMC Public Health. 2016;16(1):380.

42. Mekasha A, Zerfu M. Prevalence of anemia among school children in Addis Ababa. Ethiop Med J. 2009;47(2):129-33

43. Krivienè I, Rageliene $L$. The prevalence of anemia among schoolchildren in Šiauliai region of Lithuania. Acta Med Lituanica. 2006;13(1):56-9.

44. Sekulic MR, Stajic D, Djonovic N. The analysis of nutritional predictors of anemia combined with obesity in primary school-age children. Serbian J Exp Clin Res. 2018;19(1):65-72. https://doi.org/10.1515/sjecr-2016-0089.

45. Syed S, Addo OY, la Cruz-Góngora D, Ashour FAS, Ziegler TR, Suchdev PS, Determinants of anemia among school-aged children in Mexico, the United States and Colombia. Nutrients. 2016;8(7):387. https://doi.org/10.3390/ nu8070387.

46. Agency CS, ICF. Ethiopia Demographic and health survey 2016: key indicators report. Addis Ababa, Ethiopia, and Rockville, Maryland, USA: CSA and ICF; 2016.

47. Mesfin F, Berhane $Y$, Worku A. Anemia among primary school children in Eastern Ethiopia. PLoS One. 2015;10(4):e0123615.

48. Gutema B, Adissu W, Asress Y, Gedefaw L. Anemia and associated factors among school-age children in Filtu town, Somali region, Southeast Ethiopia. BMC Hematol. 2014;14(1):13. https://doi.org/10.1186/2052-1839-14-13. 
49. Herrador Z, Sordo L, Gadisa E, Moreno J, Nieto J, Benito A, et al. Crosssectional study of malnutrition and associated factors among school aged children in rural and urban settings of Fogera and Libo Kemkem districts, Ethiopia. PLoS One. 2014:9(9):e105880.

50. Pullan RL, Gitonga C, Mwandawiro C, Snow RW, Brooker SJ. Estimating the relative contribution of parasitic infections and nutrition for anaemia among school-aged children in Kenya: a subnational geostatistical analysis. BMJ Open. 2013;3(2):e001936. https://doi.org/10.1136/bmjopen-2012-001936.

51. Semedo MRL, Santos M, Baião M, Luiz R, da Veiga G. Anemia and associated factors among school-age children in Cape Verde, West Africa. Afr J Food Agric Nutr Dev. 2014;14(7):9511-28.

52. Luo R, Wang X, Zhang L, Liu C, Shi Y, Miller G, et al. High anemia prevalence in western China. Southeast Asian J Trop Med Public Health. 2011;42(5):1204

53. de Novaes OM, Martorell R, Nguyen P. Risk factors associated with hemoglobin levels and nutritional status among Brazilian children attending daycare centers in Sao Paulo city, Brazil. Arch Latinoam Nutr. 2010;60(1):23.

54. Kounnavong S, Sunahara T, Hashizume M, Okumura J, Moji K, Boupha B, et al. Anemia and related factors in preschool children in the southern rural Lao people's Democratic Republic. Trop Med Health. 2011;39(4):95-103. https://doi.org/10.2149/tmh.2011-13.

55. De Pee S, Bloem MW. Current and potential role of specially formulated foods and food supplements for preventing malnutrition among 6-to 23month-old children and for treating moderate malnutrition among 6-to 59month-old children. Food Nutr Bull. 2009;30(3_suppl3):S434-63.

56. Pasricha S-R, Drakesmith H, Black J, Hipgrave D, Biggs B-A. Control of iron deficiency anemia in low-and middle-income countries. Blood. 2013;121(14): 2607-17. https://doi.org/10.1182/blood-2012-09-453522.

57. Parlesak A, Geelhoed D, Robertson A. Toward the prevention of childhood undernutrition: diet diversity strategies using locally produced food can overcome gaps in nutrient supply. Food Nutr Bull. 2014;35(2):191-9. https:// doi.org/10.1177/156482651403500205.

58. Mhanna RG, Rahal M, Iskandarani M, Hammoudi D. Incidence and risk factors associated with iron deficiency anaemia among hospitalised $\mathrm{L}$ ebanese infants. Int J Pharm Pract. 2016;24(3):203-8. https://doi.org/10.1111/ ijpp.12236.

59. Jordão RE, Bernardi JLD, AdAB F. Feeding pattern and anemia in infants in the city of Campinas, São Paulo, Brazil. Rev Paul Pediatr. 2009;27(7):381-8. https://doi.org/10.1590/S0103-05822009000400006.

60. Luo R, Shi Y, Zhou H, Yue A, Zhang L, Sylvia S, et al. Anemia and feeding practices among infants in rural Shaanxi Province in China. Nutrients. 2014 6(12):5975-91. https://doi.org/10.3390/nu6125975.

61. Hallberg L, Rossander-Hultén L, Brune M, Gleerup A. Bioavailability in man of iron in human milk and cow's milk in relation to their calcium contents. Pediatr Res. 1992;31(5):524-7. https://doi.org/10.1203/00006450-19920500000024.

62. Osazuwa F, Ayo OM. Contribution of malnutrition and malaria to anemia in children in rural communities of Edo state, Nigeria. N Am J Med Sci. 2010; 2(11):532-6. https://doi.org/10.4297/najms.2010.2532.

63. Tatala S, Kihamia C, Kyungu L, Svanbergrhaaa U. Risk factors for anaemia in schoolchildren in Tanga Region, Tanzania. Tanzan J Health Res. 2008;10(4): 189-202.

\section{Publisher's Note}

Springer Nature remains neutral with regard to jurisdictional claims in published maps and institutional affiliations.

Ready to submit your research? Choose BMC and benefit from:

- fast, convenient online submission

- thorough peer review by experienced researchers in your field

- rapid publication on acceptance

- support for research data, including large and complex data types

- gold Open Access which fosters wider collaboration and increased citations

- maximum visibility for your research: over $100 \mathrm{M}$ website views per year

At BMC, research is always in progress.

Learn more biomedcentral.com/submissions 